\title{
Study of preoperative GnRh agonist in cutaneous scar endometriosis
}

\section{Nitin Naresh Kulkarni*, Alka Bhaurao Patil, Richa Patel}

Department of Obstetrics and Gynaecology, ACPM Medical College Dhule, Maharashtra, India

Received: 23 June 2016

Revised: 14 July 2016

Accepted: 05 August 2016

\section{*Correspondence:}

Dr. Nitin Naresh Kulkarni,

E-mail: kulkarnink76@gmail.com

Copyright: ( ) the author(s), publisher and licensee Medip Academy. This is an open-access article distributed under the terms of the Creative Commons Attribution Non-Commercial License, which permits unrestricted non-commercial use, distribution, and reproduction in any medium, provided the original work is properly cited.

\section{ABSTRACT}

Background: Cutaneous scar endometriosis is an uncommon pathology, it is rare and difficult to diagnose, mostly follows obstetrical and gynaecological surgeries. Surgical wide excision is the mainstay of treatment. The objective of this study was to evaluate efficacy of preoperative GnRh agonist in scar endometriosis.

Methods: This is prospective randomized case control study performed on all cutaneous scar endometriosis cases reporting to our institute as well as consultants from Dhule obstetrics and gynaecology society. All cases were operated and follow up in our institute by same surgeon.

Results: Surgical excision accompanied by preoperative GnRh agonist therapy is helpful for easy excision and reduce recurrence of scar endometriosis.

Conclusions: Abdominal scar endometriosis is rare gynecological pathology, should be suspected in any women of child bearing age group complaining of cyclical painful nodule in scar following a previous obstetric and gynaecological procedure.

Keywords: Cutaneous scar endometriosis, GnRh agonist

\section{INTRODUCTION}

Endometriosis is defined as a pathologic condition in which the endometrium, consisting of endometrial glands and stroma, is found in locations outside the endometrial lining. ${ }^{1,4}$ The commonest location of endometriosis is in the pelvis. However, endometriosis has been described in extra pelvic sites, including anterior abdominal wall, diaphragm, omentum, small intestine, appendix, lung, urinary tract, musculoskeletal, and neural systems. ${ }^{2,3}$ Cutaneous endometriosis mainly exists in abdominal scars following obstetric and gynaecologic surgery. ${ }^{5}$ Endometriosis can sometimes occur in a previous surgical scar. Scar endometriosis is rare and difficult to diagnose. It mostly follows obstetrical and gynaecological surgeries. ${ }^{5-7}$ This condition is often confused with other surgical conditions. Cutaneous scar endometriosis following caesarean section is the most frequent cutaneous form, with an incidence of 0.03
$0.4 \%$. $^{5}$ Surgical excision is the main stay of treatment. Difficult excision and recurrence is known in these cases.

The objective of this study was to highlight the role of preoperative $\mathrm{GnRh}$ agonist in scar endometriosis. And to reduce intraoperative complications and recurrence rate of disease. To reduce the morbidity and to identify other advantages if any.

\section{METHODS}

Prospective case control study. Abdominal scar endometriosis cases reporting to our institute as well as Dhule obstetrics and gynaecology society members since April 2013 to April 2016. All cases were operated in our institute after proper counseling and required consent. Follow up to our institute or respective consultant referring cases in view of post-operative morbidity and recurrence. 


\section{Inclusion criteria}

- All diagnosed cases of scar endometriosis following obstetrics and gynaecology operative procedure reporting to our institute

- Cases from Dhule obstetrics and gynaecology society members.

\section{Exclusion criteria}

- Scar endometriosis cases following non obstetrics and gynaecology operative

- Patient not willing to give consent for study

- Non abdominal cutaneous scar endometriosis.

\section{RESULTS}

There were 16 women who were treated during the period of study (Table 1). They all presented with painful lump in abdominal scar. Typically cyclic pain was present in $8(50 \%)$ cases. Majority cases followed by obstetric and gynaecological procedure such as caesarean section $(81.2 \%)$, laprotomy for rupture uterus $(12.5 \%)$ and myomectomy $(6.25 \%)$. The mean age was 29.2 years (range 22-37 years). The average nodular size was $3.6 \mathrm{~cm}$ (range $2-7 \mathrm{~cm}$ ) which were present $(70 \%)$ at the scar. Diagnoses were made in $62.5 \%$ cases by FNAC in which $37.5 \%$ cases additionally confirm by ultrasonography. Investigations done including complete blood count, urea, electrolytes.

Table 1: Clinical features, diagnostic methods, treatment and follow up.

\begin{tabular}{|c|c|c|c|c|c|c|c|}
\hline Age & Previous surgery & Symptoms & $\begin{array}{l}\text { Investigation } \\
\text { for diagnosis }\end{array}$ & $\begin{array}{l}\text { Node } \\
\text { size }\end{array}$ & $\begin{array}{l}\text { Pre-operative } \\
\text { GnRH given } \\
\text { yes/no }\end{array}$ & $\begin{array}{l}\text { Intraop } \\
\text { dissection }\end{array}$ & $\begin{array}{l}\text { Recurrence } \\
\text { yes/no }\end{array}$ \\
\hline 26 & Caesarean section & $\begin{array}{l}\text { Painful lump at } \\
\text { scar }\end{array}$ & FNAC & $3 \mathrm{~cm}$ & Yes & Uneventful & No \\
\hline 28 & Caesarean section & $\begin{array}{l}\text { Painful lump at } \\
\text { scar }\end{array}$ & FNAC & $2 \mathrm{~cm}$ & No & Uneventful & No \\
\hline 22 & Caesarean section & $\begin{array}{l}\text { Painful lump with } \\
\text { cyclical pain }\end{array}$ & $\begin{array}{l}\text { FNAC and } \\
\text { USG }\end{array}$ & $3 \mathrm{~cm}$ & Yes & Uneventful & No \\
\hline 29 & Myome-ctomy & $\begin{array}{l}\text { Painful lump with } \\
\text { cyclical pain }\end{array}$ & $\begin{array}{l}\text { FNAC and } \\
\text { USG }\end{array}$ & $4 \mathrm{~cm}$ & Yes & Uneventful & No \\
\hline 32 & Caesarean section & Painful lump & $\begin{array}{l}\text { FNAC and } \\
\text { USG }\end{array}$ & $4 \mathrm{~cm}$ & No & $\begin{array}{l}\text { Difficult } \\
\text { required } \\
\text { quartery }\end{array}$ & No \\
\hline 35 & $\begin{array}{l}\text { Laparotomy for } \\
\text { rupture uterus }\end{array}$ & $\begin{array}{l}\text { Painful lump with } \\
\text { cyclical pain }\end{array}$ & USG & $5 \mathrm{~cm}$ & Yes & Uneventful & No \\
\hline 30 & Caesarean section & $\begin{array}{l}\text { Painful tender } \\
\text { lump }\end{array}$ & USG & $2 \mathrm{~cm}$ & No & Uneventful & No \\
\hline 27 & Caesarean section & Painful lump & FNAC & $3 \mathrm{~cm}$ & No & Difficult & No \\
\hline 29 & Caesarean section & Painful lump & FNAC & $3 \mathrm{~cm}$ & Yes & Uneventful & No \\
\hline 37 & Caesarean section & $\begin{array}{l}\text { Painful lump with } \\
\text { cyclical pain }\end{array}$ & USG & $6 \mathrm{~cm}$ & No & $\begin{array}{l}\text { Difficult } \\
\text { dissection- } \\
\text { mesh } \\
\text { required }\end{array}$ & $\begin{array}{l}1 \mathrm{~cm} \\
\text { painful } \\
\text { lesion } \\
\text { noted after } \\
6 \text { month }\end{array}$ \\
\hline 31 & $\begin{array}{l}\text { Laparotomy for } \\
\text { uterine } \\
\text { perforation }\end{array}$ & $\begin{array}{l}\text { lump with } \\
\text { cyclical pain }\end{array}$ & USG & $7 \mathrm{~cm}$ & Yes & Uneventful & No \\
\hline 26 & Caesarean section & Painful lump & $\begin{array}{l}\text { FNAC and } \\
\text { USG }\end{array}$ & $3 \mathrm{~cm}$ & No & Uneventful & No \\
\hline 32 & Caesarean section & $\begin{array}{l}\text { Painful lump with } \\
\text { cyclical pain }\end{array}$ & $\begin{array}{l}\text { FNAC and } \\
\text { USG }\end{array}$ & $2 \mathrm{~cm}$ & Yes & Uneventful & No \\
\hline 28 & Caesarean section & $\begin{array}{l}\text { lump with } \\
\text { cyclical pain }\end{array}$ & $\begin{array}{l}\text { FNAC and } \\
\text { USG }\end{array}$ & $3 \mathrm{~cm}$ & No & Uneventful & No \\
\hline 24 & Caesarean section & Painful lump & USG & $4 \mathrm{~cm}$ & No & $\begin{array}{l}\text { Difficulty in } \\
\text { dissection }\end{array}$ & No \\
\hline 32 & Caesarean section & $\begin{array}{l}\text { Painful lump with } \\
\text { cyclical pain }\end{array}$ & USG & $4 \mathrm{~cm}$ & Yes & Uneventful & No \\
\hline
\end{tabular}


After explaining role of preoperative $\mathrm{GnRh}$ agonist choice is given to all diagnosed cases. Eight cases (50\%) choose to go with preoperative single dose of $\mathrm{GnRh}$ agonist $3.75 \mathrm{mg}$ intramuscularly on first day of menses. All cases were operated by same surgeon at our institute. Out of 8 cases in control group surgeon felt difficulty in dissection of 3 cases $(37.5 \%)$ in which 1 case require synthetic mesh for rectus sheath repair. In study group of 8 cases surgeon felt easy dissection, less requirement of quarterly for haemostasis.

All the patients were followed up to varying period of months (4-10 month). During this period of follow-up there was no untoward squeal in study group compare to one case of recurrence in control group.

\section{DISCUSSION}

Endometriosis was described first time by Rockitansky in and first case of scar endometriosis was reported by Meyer. ${ }^{7,8}$ It should be consider when a nodule with or without cyclic pain appears in scar following obstetrics or gynaecological operative procedure. In this study the average age at presentation was 30 years with support the literature. ${ }^{8}$ The literature reports that time of occurrence of lesions varies from months to years after operative procedures in different cases. $^{9}$

Two theories metastatic theories and metaplastic theories have been proposed regaining its pathogenesis. Clinical diagnosis is usually made by proper history taking and noting its characteristic features like site of nodule, cyclical pain and enlargement. Various differential diagnosis like stitch granuloma, incisional hernia, desmoids tumor and abscess should be thought of. ${ }^{10,11}$

Ultrasonography is the best and most commonly used investigation for abdominal lumps. Scar endometriotic nodule may appear hypoechoic and heterogeneous with internal echoes. ${ }^{12}$ MRI is also helpful modality for presurgical mapping of deep pelvic endometriosis. FNAC (fine needle aspiration cytology) was reported in some studies for confirmation of diagnosis, but as per our opinion it should be followed by ultrasonography. ${ }^{13}$ Role of FNAC should be restricted for large lesions.

Local wide excision is treatment of choice. Literature shows that larger and deeper lesions are more difficult to excise completely, may require a synthetic mesh for closure. The incidence of concomitant pelvic endometriosis with scar endometriosis have been reported to be from $14.3 \%$ to $26 \%$. $^{4,14}$

Although a rare event, malignant transformation of cutaneous scar endometriosis is a possibility. Therefore wide excision is considered as treatment of choice even for recurrent lesions and recurrence is known in patient with known history of endometriosis. ${ }^{2}$ That lead us to study measures for proper wide surgical excision and to avoid recurrence.
In literature the use of progesterone, contraceptive pill and danazol has been reported as ineffective. Role of GnRh (gonadotropin) agonist was proposed by Rivlin et al. $^{15}$

GnRh agonist work by producing a profound suppression of gonado-tropin secretion by the pituitary, resulting in a hypoestrogenic state and subsequent diminution of endometriosis lesions. The GnRh agonists on the market have been shown to work quite well in reducing all pain symptoms associated with endometriosis, including dysmenorrhea, dyspareunia, and noncyclic pelvic pain. Conflicting data exist regarding the role of $\mathrm{GnRH}$ agonists in the treatment of endometriomas, but the bulk of the evidence suggests a low degree of efficacy. GnRh agonists are often initiated with the onset of menses. No studies have yet done to see the efficacy of GnRh agonist on scar endometriosis. In our study we tried to use advantage of mechanism of action of GnRh agonist to make ease in surgeries for scar endometriosis, to avoid recurrences and may prove beneficial for concomitant pelvic endometriosis.

\section{CONCLUSION}

Abdominal scar endometriosis is rare gynaecological pathology, should be suspected in any women of child bearing age group complaining of cyclical painful nodule in scar following a previous obstetric and gynaecological procedure.

The study supports that scar endometriosis may result of transplantation of endometrial tissue during procedure.

Preoperative diagnosis is feasible with fine needle aspiration cytology (FNAC) as it provides accurate diagnosis. Ultrasonography with colour doppler is equally helpful to diagnose and identify the location and extent of lesion.

Exploration with wide excision remains the treatment of choice for abdominal scar endometriosis. However preoperative $\mathrm{GnRh}$ agonist therapy is helpful for easy excision of scar endometriosis and to prevent recurrence of disease.

\section{ACKNOWLEDGEMENTS}

Authors wish to immensely thank principle and HOD, department of pathology, ACPM Medical College. All members of Dhule OBGY society for their help to complete the research.

Funding: No funding sources Conflict of interest: None declared

Ethical approval: The study was approved by the Institutional Ethics Committee 


\section{REFERENCES}

1. Nahir B, Eldar-Geva T, Alberton J, Beller U. Symptomatic diaphragmatic endometriosis ten years after total abdominal hysterectomy. Obstetrics and gynecology. 2004;104(5):1149-51.

2. Drukala Z, Ciborowska-Zielińska B, Kubrak J, Rodgowska D. Outcome of a multimodal therapy of a recurrent adenocarcinoma arising from Caesarean section scar endometriosis- a case report. Reports of Practical Oncology and Radiotherapy. 2010;15(3).

3. Jubanyik KJ, Committee F. Extrapelvic endometriosis. Obstetrics and Gynecology Clinics of North America. 1997;24(2):411-40.

4. Medeiros FD, Cavalcante DI, Medeiros MA, Eleuterio J. Fine-Need leaspiration cytology of scar endometriosis: study of seven cases and literature review. Diagn Cytopathol. 2011;39:18-21.

5. Nominato SN, Prates LF, Lauar I, Morais J, Maia L, Geber S. Caesarean section greatly increases the risk of scar endometriosis. European Journal of Obstetrics and Gynecology and Reproductive Biology. 2010;152:83-5.

6. Dwivedi AJ, Agrawal SN, Silva YJ. Abdominal wall endometrioma. Digestive Diseases and Sciences. 2002;47(2):456-61.

7. Medeiros FD, Cavalcante DI, Medeiros MA, Eleuterio J. Fine-needle aspiration cytology of scar endometriosis: study of seven literature review. Diagn Cytopathol. 2011;39:18-21.
8. Pathan ZA, Dinesh US, Rao R. Scar endometriosis. J Cytology. 2010;27:106-8.

9. Koger KE, Shatney CH, Hodge K, McClenathan JH. Surgical scar endometrioma. Surgery Gynecology and Obstetrics. 1993;177(3):243-6.

10. Wolf Y, Haddad R, Werbin N, Skornick Y, Kaplan O. Endometriosis in abdominal scars: a diagnostic pitfall. American Surgeon. 1996;62(12):1042-4.

11. Aydin O. Scar endometriosis a gynaecologic pathology often presented to the general surgeon rather than the gynaecologist: report of two cases. Langenbeck's Archives of Surgery. 2007;392(1):105-9.

12. Picod G, Boulanger L, Bounoua F, Leduc F, Duval G. Abdominal wall endo-metriosis after cesarean section: report of fifteen cases. Gynecol Obstet Fertil. 2006;34:8-13.

13. Pathan SK, Kapila K, Haji BE, Mallik MK, AlAnsary TA, George SS, et al. Cytomorphological spectrum in scar endometriosis: a study of eight cases. Cytopathology. 2005;16(2):94-9.

14. Rani PR, Soundararaghavan S, Rajaram P. Endometriosis in abdominal scars review of 27 cases. International Journal of Gynecology and Obstetrics. 1991;36(3):215-8.

15. Rivlin ME, Das SK, Patel RB, Meeks GR. Leuprolide acetate in the management of cesarean scar endometriosis. Obstet Gynecol. 1995;85:838-9.

Cite this article as: Kulkarni NN, Patil AB, Patel R. Study of preoperative GnRh agonist in cutaneous scar endometriosis. Int J Reprod Contracept Obstet Gynecol 2016;5:3191-4. 